\title{
EPR and Semi-Empirical Studies as Tools to Assign the Geometric Structures of $\mathrm{Fe}^{\mathrm{III}}$ Isomer Models for Transferrins
}

\author{
Marciela Scarpellini, ${ }^{*, a, b}$ Annelise Casellato, ${ }^{a}$ Adailton J. Bortoluzzi, ${ }^{a}$ Ivo Vencato, ${ }^{a, c}$ \\ Antonio S. Mangrich, ${ }^{d}$ Ademir Neves ${ }^{a}$ and Sérgio P. Machado ${ }^{*, b}$ \\ ${ }^{a}$ Departamento de Química, Universidade Federal de Santa Catarina, Trindade, \\ 88040-900 Florianópolis - SC, Brazil \\ ${ }^{b}$ Instituto de Química, Universidade Federal do Rio de Janeiro \\ 21945-970, Rio de Janeiro - RJ, Brazil \\ ${ }^{c}$ Instituto de Física, Universidade Federal de Goiás, \\ 74001-970 Goiânia - GO, Brazil \\ ${ }^{d}$ Departamento de Química, Universidade Federal do Paraná, \\ 81531-970 Curitiba - PR, Brazil
}

A reação entre $\mathrm{Fe}\left(\mathrm{ClO}_{4}\right)_{3} \cdot \mathrm{nH}_{2} \mathrm{O}$ e $N, N^{\prime}$-bis[(2-hidroxibenzil)- $N, N^{\prime}$-bis(1-metilimidazol-2-ilmetil)] etilenodiamina ( $\mathrm{H}_{2}$ bbimen) resulta na formação de dois isômeros geométricos, $\mathbf{A}$ e $\mathbf{B}$, do cátion complexo $[\mathrm{Fe}(\text { bbimen })]^{+}$, os quais foram isolados e caracterizados por espectroscopia na região do infravermelho e UV-visível, espectrometria de massas, medidas de condutividade molar, voltametria cíclica, espectroeletroquímica e espectroscopia de ressonância paramagnética eletrônica (RPE). A geometria de um desses isômeros foi claramente demonstrada por análise cristalográfica de raios $\mathrm{X}$ de monocristal. O composto cristaliza no sistema monoclínico, grupo espacial P2/c, a = 14,104 (3), $\mathrm{b}=15,626$ (3), $\mathrm{c}=13,291$ (3) $\AA, \beta=98,07$ (3) $, \mathrm{Z}=4, \mathrm{R}_{1}=6,35 \%$ e $w \mathrm{R}_{2}=20,57 \%$. As propriedades eletroquímicas do cátion [Fe(bbimen) $]^{+}(-0,58 \mathrm{~V}$ versus $\mathrm{NHE})$ são bastante similares às das transferrinas (-0,52 V versus NHE), indicando que o complexo é um bom modelo para as propriedades redox daquelas metaloenzimas. A espectroscopia de RPE foi a única técnica espectroscópica capaz de diferenciar os dois isômeros isolados (A e B). Os estudos de RPE revelaram que o isômero A trata-se de um complexo de $\mathrm{Fe}^{\mathrm{III}}$ spin alto distorcido rombicamente $(\mathrm{E} / \mathrm{D} \cong 0,33)$ e apresenta um espectro caracterizado por uma linha estreita em $g_{1} \cong 4,1$ e outra larga em $g_{2} \cong 9,0$. O espectro de RPE do isômero B apresenta, além das linhas em $g_{1} \cong 4,2$ e em $g_{2} \cong 9,0$, um conjunto de linhas em $g_{1} \cong 3,0$, $g_{2} \cong 3,6$ e $g_{3} \cong 5,1$, que têm sido atribuídas a complexos de $\mathrm{Fe}^{\mathrm{III}}$ com simetria tendendo à axial (E/ $\mathrm{D} \cong 0,22$ ). Estudos teóricos empregando cálculos semi-empíricos, combinados com os dados de RPE, foram essenciais para a atribuição das estruturas geométricas dos isômeros $\mathbf{A}$ e $\mathbf{B}$.

The reaction of $\mathrm{Fe}\left(\mathrm{ClO}_{4}\right)_{3} \cdot \mathrm{nH}_{2} \mathrm{O}$ with $N, N^{\prime}$-bis[(2-hydroxybenzyl)- $N, N^{\prime}$-bis(1-methylimidazole2-yl-methyl)]ethylenediamine ( $\mathrm{H}_{2}$ bbimen) affords two geometric isomers, $\mathbf{A}$ and $\mathbf{B}$, of the complex cation $[\mathrm{Fe}(\text { bbimen })]^{+}$, which were fully characterized by IR and UV-visible spectroscopies, ESI mass spectrometry, molar conductivity measurements, cyclic voltammetry, spectroelectrochemistry and EPR spectroscopy. The geometry of one of these isomers has been clearly demonstrated through X-ray crystallographic analysis. It crystallizes in the monoclinic system, space group $\mathrm{P} 2 / \mathrm{c}, \mathrm{a}=14.104$ (3), $\mathrm{b}=15.626(3), \mathrm{c}=13.291(3) \AA, \beta=98.07(3)^{\circ}, \mathrm{Z}=4, \mathrm{R}_{1}=6.35 \%$ and $\mathrm{wR}_{2}=20.57 \%$. The electrochemical properties of $[\mathrm{Fe}(\text { bbimen })]^{+}(-0.58 \mathrm{~V}$ versus $\mathrm{NHE})$ are quite similar to those of transferrins $(-0.52 \mathrm{~V}$ versus $\mathrm{NHE}$ ) and indicate that it is a good model for the redox potential of these metalloenzymes. EPR spectroscopy was the only spectroscopic technique able to differentiate the isolated isomers $\mathbf{A}$ and $\mathbf{B}$. EPR studies revealed that isomer $\mathbf{A}$ is better described as a rhombically distorted $(\mathrm{E} / \mathrm{D} \cong 0.33$ ) highspin $\mathrm{Fe}^{\mathrm{III}}$ complex $\left(g_{l} \cong 4.1\right.$ with a shoulder at $g_{2} \cong 9.0$ ), while the spectrum of $\mathbf{B}$ has a set of lines at $g_{1} \cong 3.0, g_{2} \cong 3.6$ and $g_{3} \cong 5.1$, in addition to the line at $g_{1} \cong 4.2$ and a shoulder at $g_{2} \cong 9.0$, which have been ascribed to $\mathrm{Fe}^{\mathrm{III}}$ complexes in axial symmetry $(\mathrm{E} / \mathrm{D} \cong 0.22)$. Semi-empirical theoretical studies, combined with EPR data, were essential to the proposition of the geometric structures of $\mathbf{A}$ and $\mathbf{B}$.

Keywords: Fe ${ }^{\mathrm{III}}$ complex, geometric isomers, EPR, transferrins, semi-empirical studies

*e-mail: sergiopm@iq.ufrj.br 


\section{Introduction}

Transferrins (Tfs), or siderophilins, are a family of Fe-binding proteins belonging to the Fe-tyrosinate class. In vertebrates, they are found in blood (serum transferrin), eggs (ovotransferrin) and milk (lactoferrin). The main physiological role of serum transferrin is the Fe transport through the circulating blood and its release to the Fedependent cells. Another role is believed to be played by ovotransferrin and lactoferrin, which involves bacteriostatic effects. ${ }^{1,2}$ As the serum concentration of transferrin is about $35 \mu \mathrm{mol} \mathrm{L}-1$, and about $70 \%$ of it is in the apo-form (protein depleted of $\mathrm{Fe}$ ), it is also proposed to be a blood transporter of several other metal ions, including vanadium, aluminum, gallium and cobalt. ${ }^{3}$ Of the Fe-dependent cells, tumor cells are probably the ones of most concern because of their high demand for iron and as a consequence they exhibit enhanced transferrin receptor (TfR) expression. ${ }^{4}$

During the lifetime of serum transferrin in the circulation system, it is able to perform reverse uptake and deliver $\mathrm{Fe}$ about 100-200 times, and thus an understanding of the kinetics and the mechanism involved in the fundamental physiological process is of interest. ${ }^{5}$ It has been proposed that the first step is the coordination of $\mathrm{Fe}^{\mathrm{III}}$ to transferrin, which is coupled to the synergistic binding of a carbonate ion. The $\mathrm{Fe}^{\mathrm{III}}$-Tf complex is then transported through the blood to the Fe-dependent cells, where the $\mathrm{Fe}^{\mathrm{III}}$-Tf complex binds to a membrane transferrin receptor. This system is then internalized by the cell to an ATP-driven proton-pumping endosome ( $\mathrm{pH}$ 5.4-6.0), where the metal is released as $\mathrm{Fe}^{\mathrm{II}}$. This then leaves the endosome via a membrane metal ion transporter (DMT). ${ }^{6}$

In order to better understand this process, the full characterization of transferrins is of fundamental importance. The structures of human lactoferrin, ${ }^{7}$ serum transferrin, ${ }^{8,9}$ and duck ovotransferrin ${ }^{10}$ have all been well studied using X-ray crystallography and are quite similar. They are bilobal proteins with each domain $(\mathrm{C}-$ and $\mathrm{N}$ lobes) binding one $\mathrm{Fe}^{\mathrm{III}}$ ion. As the $\mathrm{Fe}^{\mathrm{III}}$ uptake is carbonatedependent, its coordination sphere is composed of the two oxygen atoms of this "synergistic" ion, two phenolate oxygen atoms from tyrosine residues, one imidazole nitrogen atom from histidine and one carboxylate oxygen from aspartic acid (Figure 1)..$^{7-10}$

In addition to the structural characterization, transferrins have also been investigated using other techniques. Human lactoferrin gives an electronic spectrum characterized by two ligand-to-metal charge transfer (LMCT) bands at $465 \mathrm{~nm}$ and $280 \mathrm{~nm}$, both ascribed to tyrosinate $\rightarrow \mathrm{Fe}^{\mathrm{III}}$ charge transfer transitions. ${ }^{11}$

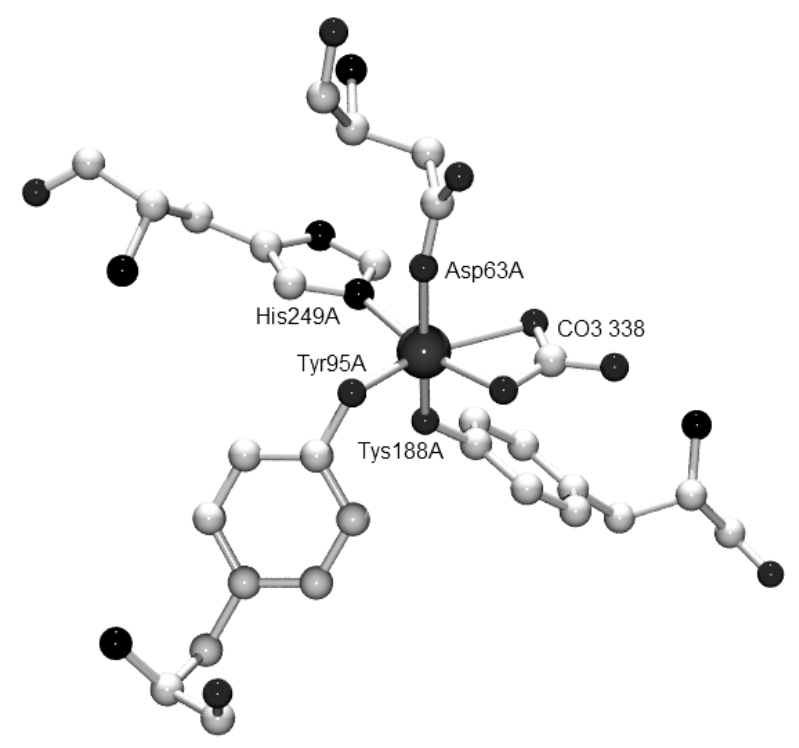

Figure 1. Graphic representation of the active site of human lactoferrin based on coordinates from the PDB file from reference 9 (1D3K).

Mössbauer spectra of human lactoferrin and serum transferrin display isomer shifts of $0.39 \mathrm{~mm} \mathrm{~s}^{-1}$ and 0.38 $\mathrm{mm} \mathrm{s}^{-1}$ respectively, which are typical of high-spin $\mathrm{Fe}^{\mathrm{III}}$ centers. ${ }^{12}$ Additionally, the serum transferrin spectrum shows a large quadrupole splitting reflecting the nonsymmetrical coordination field around the $\mathrm{Fe}^{\mathrm{III}}$ ion, as shown by the structural analysis. ${ }^{8,11}$ In agreement with the Mössbauer data, the EPR spectrum of serum transferrin displays a sharp signal at $g \cong 4.3$ and a shoulder at $g \cong 9.0$, both characteristics of high-spin $\mathrm{Fe}^{\mathrm{III}}$ ions. ${ }^{12}$

As the iron transport involves the uptake of $\mathrm{Fe}^{\mathrm{III}}$ and the release of $\mathrm{Fe}^{\mathrm{II}}$ ions, knowledge of the redox potentials of Fe-bonded transferrins is extremely important. Redox potentials of human serum transferrin have been investigated under physiological (7.4) and endosomal (5.8) $\mathrm{pH}$ conditions. Spectroelectrochemical measurements ${ }^{13}$ revealed that $\mathrm{E}_{1 / 2}=-0.52(8) \mathrm{V}$ versus $\mathrm{NHE}$ at $\mathrm{pH}$ 7.4. At $\mathrm{pH} 5.8$, the redox potentials $\left(\mathrm{E}_{1 / 2}\right)$ of the three possible $\mathrm{Fe}^{\mathrm{III}}$-Tf forms were measured: the diferric $\left(\mathrm{E}_{1 / 2}=-0.526 \mathrm{~V}\right.$ versus $\mathrm{NHE})$, the monoferric C-lobe $\left(\mathrm{E}_{1 / 2}=-0.501 \mathrm{~V}\right.$ versus $\mathrm{NHE})$ and the monoferric $\mathrm{N}$-lobe $\left(\mathrm{E}_{1 / 2}=\right.$ $-0.520 \mathrm{~V}$ versus $\mathrm{NHE}$ ) forms. ${ }^{14}$ All of these measured redox potentials are too low for reduction of $\mathrm{Fe}^{\mathrm{III}}$ by physiological agents. However, it has recently been demonstrated that the interaction of the $\mathrm{Fe}^{\mathrm{III}}$ - Tf complex with the membrane transferrin receptor (TfR) raises the potential by more than $200 \mathrm{mV}$, explaining the $\mathrm{Fe}^{\mathrm{III}} \rightarrow \mathrm{Fe}^{\mathrm{II}}$ reduction in physiological medium. ${ }^{6}$

Based on these studies, several articles have been published reporting $\mathrm{Fe}^{\mathrm{III}}$ complexes with phenolate- and pyridine/imidazole-containing ligands as models for $\mathrm{Fe}$ - 
tyrosinate proteins..$^{15-20}$ Very recently, we reported ${ }^{16}$ the synthesis and full characterization of a series of $\mathrm{Fe}^{\mathrm{III}}$ complexes, $[\mathrm{Fe}(\text { bbpen- } \mathrm{X})]^{+}$, using hexadentate ligands $\left(\mathrm{H}_{2}\right.$ bbpen-X) containing pyridine and phenol pendant arms. In this paper, we show that the reaction of the analogous $\mathrm{H}_{2}$ bbimen (Scheme 1) with $\mathrm{Fe}\left(\mathrm{ClO}_{4}\right)_{3} \cdot \mathrm{nH}_{2} \mathrm{O}$ affords a mixture of geometric isomers ( $\mathbf{A}$ and $\mathbf{B})$, which were only differentiated by EPR analysis. In order to determine the structure of the $\mathrm{Fe}^{\mathrm{III}}$ complexes, semiempirical studies were a helpful tool when combined with EPR spectroscopic data.

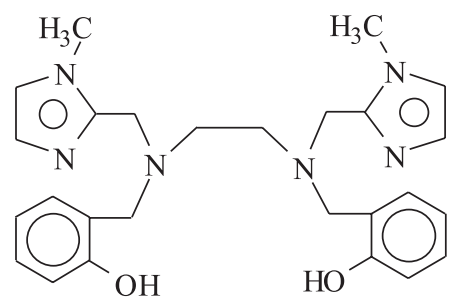

$\mathrm{H}_{2}$ bbimen

Scheme 1.

\section{Experimental}

\section{Abbreviations}

$\mathrm{H}_{2}$ bbpen, $N, N^{\prime}$-bis-(2-hydroxybenzyl)- $N, N^{\prime}$-bis-(2pyridin-2-yl-methyl)ethylenediamine; $\mathrm{H}_{2}$ bbimen, $N, N^{\prime}$ bis-(2-hydroxybenzyl)- $N, N$ '-bis-(1-methylimidazole-2-ylmethyl)ethylenediamine; $\mathrm{TBAPF}_{6}$, tetra-n-butylamonium hexafluorophosphate; ESI-MS, electrospray ionization mass spectrometry; CV, cyclic voltammetry; IR, infrared spectroscopy; EPR, electron paramagnetic resonance spectroscopy; SCE, standard calomel electrode; Fc, ferrocene; $\mathrm{Fc}^{+}$, ferrocenium ion; NHE, normal hydrogen electrode.

\section{Materials}

Electrochemical and spectroscopic data were collected in high purity solvents, and high purity argon was used when necessary to obtain inert atmosphere. All other chemicals and solvents were of reagent grade, purchased from commercial sources, and used without further purification.

\section{Physical measurements}

Infrared spectra were obtained on a FT-IR PerkinElmer 16PC spectrophotometer as $\mathrm{KBr}$ pellets or films. Elemental analyses were performed on a CHN PerkinElmer 2400 analyser. Molar conductivity was measured in $\mathrm{CH}_{3} \mathrm{CN}\left(10^{-3} \mathrm{~mol} \mathrm{~L}^{-1}\right)$ at $298 \mathrm{~K}$ with a Digimed CD-21 equipament. Electrospray-ionization (ESI-MS) mass spectra were recorded in acetonitrile using a Micromass LCT time-of-flight mass spectrometer with electrospray and APCI, coupled to a Waters 1525 Binary HPLC pump. UV-visible absorption spectra were measured in $\mathrm{CH}_{3} \mathrm{CN}$ on a Perkin-Elmer Lambda 19 spectrophotometer. Cyclic voltammograms were recorded at room temperature using a PAR 273 (Princeton Applied Research) potentiostat in acetonitrile solution, under argon atmosphere, with $\operatorname{TBAPF}_{6}\left(0.1 \mathrm{~mol} \mathrm{~L}^{-1}\right)$ as supporting electrolyte. A standard three-electrode cell was used: a gold working electrode, a platinum wire auxiliary electrode and a SCE reference electrode. Ferrocene was used as internal standard $\left(\mathrm{E}_{1 / 2}=0.16 \mathrm{~V}\right.$ versus $\left.\mathrm{SCE}\right) .{ }^{22}$ Spectroelectrochemical experiments were carried out at room temperature in acetonitrile, under argon, with $\operatorname{TBAPF}_{6}\left(0.1 \mathrm{~mol} \mathrm{~L}^{-1}\right)$ as supporting electrolyte, using an optically transparent thinlayer cell constructed according a previously reported procedure. ${ }^{23} \mathrm{~A}$ gold minigrid and a platinum wire were used, respectively, as working and auxiliary electrodes, and a SCE was used as the reference electrode. Potentials were applied with a PAR 263 potentiostat/galvanostat and the spectra were recorded with a Perkin-Elmer Lambda 19 spectrophotometer. Spectral changes were registered after the establishment of equilibrium (120 s) and the experiment was stopped when no further changes were observed. Potentials were applied in the range of -0.84 to $-1.06 \mathrm{~V}$ versus $\mathrm{Fc}^{+} / \mathrm{Fc}$ and the spectra recorded from 300 to $750 \mathrm{~nm}$. The $\mathrm{Fc}^{+} / \mathrm{Fc}$ couple was used separately to monitor ${ }^{22}$ the reference electrode $\left(\mathrm{E}_{1 / 2}=0.16 \mathrm{~V}\right.$ versus SCE). X-band EPR spectra were recorded on a Bruker ESP $300 \mathrm{E}$ spectrometer at $77 \mathrm{~K}$ in $\mathrm{CH}_{2} \mathrm{Cl}_{2}$ solution.

\section{Synthesis of [ $\mathrm{Fe}($ bbimen $)] \mathrm{ClO}_{4}$}

Mixture of isomers (1). $\mathrm{Fe}\left(\mathrm{ClO}_{4}\right)_{3} \cdot \mathrm{nH}_{2} \mathrm{O}(0.36 \mathrm{~g}, 1 \mathrm{mmol})$ was slowly added to a methanolic solution of $\mathrm{H}_{2}$ bbimen $(0.46 \mathrm{~g}, 1 \mathrm{mmol}, 30 \mathrm{~mL})$. This reaction mixture was heated $\left(\sim 40{ }^{\circ} \mathrm{C}\right)$ under stirring for $c a .30 \mathrm{~min}$. After cooling the solution to room temperature, a violet microcrystalline precipitate was filtered off, washed with small amounts of cold 2-propanol and dried under vaccum. Yield $0.40 \mathrm{~g}$ (62\%). FT-IR ( $\mathrm{KBr}$ pellet) $v_{\max } / \mathrm{cm}^{-1}: v(\mathrm{O}-\mathrm{H}) 3426$; $v\left(\mathrm{C}=\mathrm{N}_{\text {imidazole }}\right) 1592 ; v(\mathrm{C}=\mathrm{C}) 1514-1446$; $v\left(\mathrm{C}-\mathrm{O}_{\text {phenol }}\right) 1278$; $v(\mathrm{Cl}-\mathrm{O}) 1154$ and 1094. ESI-MS $\mathrm{m} / z$ (positive mode): $512.2(6.38 \%), 513.2(2.25 \%), 514.2(100 \%), 515.2$ $(32.63 \%)$ and $516.2(5.88 \%)$. Anal. Calc. for $\mathrm{FeC}_{28} \mathrm{H}_{38}$ $\mathrm{N}_{6} \mathrm{O}_{8} \mathrm{Cl}: \mathrm{C}, 49.61 ; \mathrm{H}, 5.65 ; \mathrm{N}, 12.40$. Found: C, 49.62; H, $5.11 ; \mathrm{N}, 12.64 \%$. Molar conductivity: $130 \Omega^{-1} \mathrm{~cm}^{2} \mathrm{~mol}^{-1}$ in acetonitrile at $298 \mathrm{~K}(1: 1$ electrolyte $){ }^{24}$ Few single 
crystals suitable for X-ray crystallographic analyses were obtained by slow evaporation of a solution of $\mathbf{1}$ in methanol:ethanol:water (10:1:1).

While attempting to find solvent systems to recrystallize the product, we were able to isolate two geometric isomers of $[\mathrm{Fe}($ bbimen $)] \mathrm{ClO}_{4}$ by fractional crystallization. About $60 \%$ of the mixture of isomers (1) is soluble in hot acetone (isomer $\mathbf{A}$ ) and was recrystallized in this solvent, yielding sharp purple needles that were not suitable for X-ray analysis. The remaining amount (isomer $\mathbf{B}$ ) was then recrystallized in methanol yielding a microcrystalline sample.

Isomer A. ESI-MS $\mathrm{m} / \mathrm{z}$ (positive mode): 512.2 (6.41\%), $513.2(2.25 \%), 514.2(100 \%), 515.2(32.73 \%)$ and 516.2 $(5.89 \%)$.

Isomer B. ESI-MS $\mathrm{m} / \mathrm{z}$ (positive mode): 512.2 (6.16\%), $513.2(2.26 \%), 514.2(100 \%), 515.2(32.49 \%)$ and 516.2 (5.87\%).

Caution! Perchlorate salts of metal complexes with organic ligands are potentially explosive, and only small amounts should be carefully handled.

\section{$X$-ray crystallography}

A violet crystal was selected and isolated for crystallographic analysis with a CAD-4 diffractometer. Cell parameters were determined from 25 carefully centered reflections in the $\theta$ range $8.79-15.25^{\circ}$ using a standard procedure. ${ }^{25}$ Data were corrected for Lorentz and polarization effects ${ }^{26}$ and for absorption ${ }^{27}$ (transmission factors 0.7305 and 0.9546 ). The structure was solved with SIR $97^{28}$ and refined by full-matrix least-square methods using SHELXL97. ${ }^{29}$ The disorder in the perchlorate ion was modeled with two alternative positions for each oxygen atom. At $\mathrm{C} 7, \mathrm{C} 8$ and $\mathrm{C} 2 \mathrm{E}$, the $\mathrm{H}$ atoms were also placed using a standard disordered model. All non-H atoms were refined with anisotropic displacement parameters, except for O22. Hydrogen atoms were added at calculated positions and included in the structure factor calculations, with $\mathrm{C}-\mathrm{H}=0.93 \AA(0.96 \AA$ for methyl groups $)$ and $\mathrm{U}_{\text {iso }}(\mathrm{H})=$ $1.2 \mathrm{U}_{\text {eq }}(\mathrm{C})$ or $1.5 \mathrm{U}_{\text {eq }}$ (methyl $\mathrm{C}$ ). Other selected crystallographic information is shown in Table 1.

\section{Theoretical calculations}

All geometry optimizations were performed using semi-empirical PM3 ${ }^{\mathrm{TM}}$ molecular orbital calculation using the Spartan 04 program. ${ }^{33}$ Theoretical vibrational frequencies were used to find the minimum geometries.
Table 1. Selected crystal data and structure refinement for [Fe(bbimen)] $\mathrm{ClO}_{4} \cdot \mathrm{EtOH}$

\begin{tabular}{ll}
\hline Empirical formula & $\mathrm{C}_{28} \mathrm{H}_{36} \mathrm{ClFeN}_{6} \mathrm{O}_{7}$ \\
Formula weight & 659.93 \\
Temperature & $293(2) \mathrm{K}$ \\
Wavelength & $0.71073 \AA$ \\
Crystal system & Monoclinic \\
Space group & $\mathrm{P}_{1} / \mathrm{c}$ \\
Unit cell dimensions & \\
a & $14.104(3) \AA$ \\
$\mathrm{b}$ & $15.625(3) \AA$ \\
$\mathrm{c}$ & $13.291(3) \AA$ \\
$\beta$ & $98.07(3)^{\circ}$ \\
Volume & $2900.0(11) \AA^{3}$ \\
$\mathrm{Z}$ & 4 \\
Density (calculated) & $1.511 \mathrm{Mg} \mathrm{\textrm {m } ^ { - 3 }}$ \\
Absorption coefficient & $0.670 \mathrm{~mm}^{-1}$ \\
F(000) & 1380 \\
Crystal size & $0.50 \times 0.17 \times 0.07 \mathrm{~mm}^{3}$ \\
Theta range for data collection & 2.36 to $24.98^{\circ}$. \\
Index ranges & $-16 \leq \mathrm{h} \leq 16,0 \leq \mathrm{k} \leq 18,0 \leq 1 \leq 15$ \\
Reflections collected & 5280 \\
Independent reflections & $5049[\mathrm{R}(\mathrm{int})=0.0347]$ \\
Refinement method & $\mathrm{Full-matrix} \mathrm{least-squares} \mathrm{on} \mathrm{F}^{2}$ \\
Data / restraints / parameters & $5049 / 142 / 420$ \\
Goodness-of-fit on $\mathrm{F}^{2}$ & 1.104 \\
Final R indices [I>2 $\sigma(\mathrm{I})]$ & $\mathrm{R}_{1}=0.0635, \mathrm{wR}_{2}=0.1442$ \\
$\mathrm{R}$ indices (all data) & $\mathrm{R}_{1}=0.1529, \mathrm{wR}_{2}=0.2057$ \\
Largest diff. peak and hole & 0.686 and $-0.608 \mathrm{e} \AA^{-3}$ \\
\hline &
\end{tabular}

This method has been successfully used in cases involving transition metal complexes. ${ }^{30-32}$ The spin state of the $\mathrm{Fe}^{\mathrm{III}}$ isomers was stated as high-spin, ground state ${ }^{6} \mathrm{~S}$, according to the EPR data. The calculations were carried out on a $2.6 \mathrm{GHz}$ Athlon PC, with $1 \mathrm{~GB}$ RAM and $40 \mathrm{~Gb} \mathrm{HD}$, under the Windows 2000 operational system.

\section{Results and Discussion}

\section{Synthesis}

$\mathrm{H}_{2}$ bbimen was prepared in good yield as previously described. ${ }^{21}$ It reacts with $\mathrm{Fe}\left(\mathrm{ClO}_{4}\right)_{3} \cdot \mathrm{nH}_{2} \mathrm{O}$ in methanol to give a mixture (1) of geometric isomers ( $\mathbf{A}$ and $\mathbf{B}$ ) of the stable cation complex $[\mathrm{Fe}(\text { bbimen })]^{+}$. The mixture was separated by fractional crystallization in hot acetone.

\section{$X$-ray structural characterization}

A single crystal suitable for X-ray analysis was isolated from 1, i.e., from the mixture of isomers. The structure of the complex consists of a discrete mononuclear cation, $[\mathrm{Fe} \text { (bbimen) }]^{+}$, and a $\mathrm{ClO}_{4}^{-}$counterion, in general positions. The elemental cell also possesses an ethanol molecule as crystallization solvent. Crystallographic data and main bond distances and angles are presented in Tables 
1 and 2, respectively. X-ray crystallographic analysis shows that the $\mathrm{Fe}^{\mathrm{III}}$ center is in a pseudo-octahedral environment, with the two halves of the bbimen ${ }^{2-}$ ligand coordinated in a facial mode (Figure 2). This same arrangement $\left(f a c-\mathrm{N}_{2} \mathrm{O}\right)$ is observed in other complexes with the analogous hexadentate bbpen ${ }^{2-}$ ligand: $\left[\mathrm{Fe}^{\mathrm{III}}(\text { bbpen })\right]^{+},{ }^{16,20}\left[\mathrm{~V}^{\mathrm{IIII}}(\text { bbpen })\right]^{+},{ }^{34}$ and $\left[\mathrm{Mn}^{\mathrm{III}}(\text { bbpen })\right]^{+} .{ }^{23}$ The equatorial plane is geometrically defined by the O1O2-N1-N2 atoms, from which the $\mathrm{Fe}^{\mathrm{III}}$ deviates only 0.001 $\AA$. The equatorial plane is then composed of two nitrogen and two oxygen atoms from the ethylenediamine backbone and the phenolate groups, respectively. They are coordinated in such a way that the nitrogen atoms are cis to each other, and trans to the oxygen atoms. Completing the coordination sphere of the metal center are the two nitrogen atoms from the 1-methylimidazole group. The octahedral geometric distortion can be observed by the angles of the $\mathrm{Fe}^{\mathrm{III}}$ coordination sphere that deviate from $90^{\circ}$ (Table 2). The coordination of the ethylenediamine group results in a distorted five-membered ring (FeN2C5C6N1), in which the C5 and C6 atoms lie at opposite sides of the equatorial plane, with deviations of - 0.358 and $0.202 \AA$, respectively.

Table 2. Selected bond lengths and angles, $\AA$ or $\left(^{\circ}\right)$, for [Fe(bbimen)] $\mathrm{ClO}_{4} \cdot \mathrm{EtOH}$

\begin{tabular}{ll}
\hline $\mathrm{Fe}-\mathrm{O} 1$ & $1.877(5)$ \\
$\mathrm{Fe}-\mathrm{O} 2$ & $1.891(5)$ \\
$\mathrm{Fe}-\mathrm{N} 41$ & $2.114(6)$ \\
$\mathrm{Fe}-\mathrm{N} 31$ & $2.116(6)$ \\
$\mathrm{Fe}-\mathrm{N} 1$ & $2.269(5)$ \\
$\mathrm{Fe}-\mathrm{N} 2$ & $2.272(6)$ \\
& \\
$\mathrm{O} 1-\mathrm{Fe}-\mathrm{O} 2$ & $101.9(2)$ \\
$\mathrm{O} 1-\mathrm{Fe}-\mathrm{N} 41$ & $99.6(2)$ \\
$\mathrm{O} 2-\mathrm{Fe}-\mathrm{N} 41$ & $92.1(2)$ \\
$\mathrm{O} 1-\mathrm{Fe}-\mathrm{N} 31$ & $92.1(2)$ \\
$\mathrm{O} 2-\mathrm{Fe}-\mathrm{N} 31$ & $97.4(2)$ \\
$\mathrm{N} 41-\mathrm{Fe}-\mathrm{N} 31$ & $163.0(2)$ \\
$\mathrm{O} 1-\mathrm{Fe}-\mathrm{N} 1$ & $88.9(2)$ \\
$\mathrm{O} 2-\mathrm{Fe}-\mathrm{N} 1$ & $165.2(2)$ \\
$\mathrm{N} 41-\mathrm{Fe}-\mathrm{N} 1$ & $76.0(2)$ \\
N31-Fe-N1 & $92.1(2)$ \\
$\mathrm{O} 1-\mathrm{Fe}-\mathrm{N} 2$ & $163.3(2)$ \\
$\mathrm{O} 2-\mathrm{Fe}-\mathrm{N} 2$ & $91.3(2)$ \\
N41-Fe-N2 & $90.0(2)$ \\
N31-Fe-N2 & $75.9(2)$ \\
N1-Fe-N2 & $80.1(2)$ \\
C11-O1-Fe & $134.0(4)$ \\
C21-O2-Fe & $128.9(4)$ \\
\hline
\end{tabular}

The coordination of the phenolate groups in the equatorial plane has been observed in several other $\mathrm{Fe}^{\mathrm{III}}$ complexes: $[\mathrm{Fe}(\text { bbpen })]^{+},{ }^{16,20}[\mathrm{Fe} \text { (ehpg) }]^{-, 36}[\mathrm{Fe} \text { (hbed) }]^{-},{ }^{36}[\mathrm{Fe}$ (ehgs) $\left.\left(\mathrm{CH}_{3} \mathrm{OH}\right)\right]^{-, 37}\left[\mathrm{Fe}(\text { salen })(\mathrm{Im})_{2}\right]^{-, 38}\left[\mathrm{Fe} \text { (sal }{ }_{2} \text { trien) }\right]^{+},{ }^{39}[\mathrm{Fe}$ (salen) (4-mim) $\left.{ }_{2}\right]^{+,}{ }^{+8}$ and $[\mathrm{Fe}($ salen $)(1-\mathrm{mim}) \mathrm{Cl}] .^{38} \mathrm{The} \mathrm{Fe}-\mathrm{O}_{\mathrm{ph}}$ average

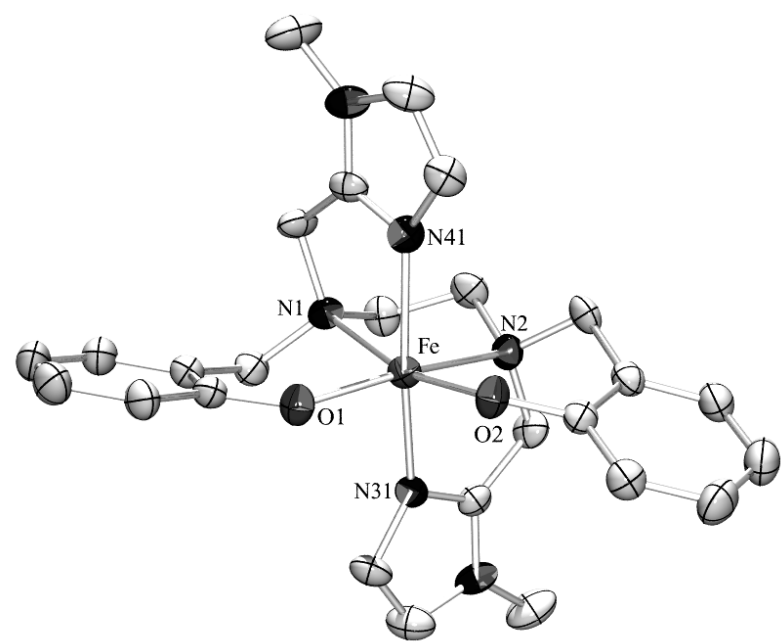

Figure 2. ORTEP ${ }^{35}$ view of $[\mathrm{Fe}(\mathrm{bbimen})]^{+}$, showing the atom labeling and the $40 \%$ probability ellipsoids.

bond distance $(1.884 \AA$ ) is very similar to that reported for $[\mathrm{Fe}(\mathrm{bbpen})]^{+}(1.87 \AA)$. Also, these distances are the shortest of the coordination sphere and, as a consequence of the trans influence, make the $\mathrm{Fe}-\mathrm{N}_{\text {am }}$ the longest ones (av. 2.270 $\mathrm{A}$ ). A comparison of the average $\mathrm{Fe}-\mathrm{N}$ bond distances in the axial positions shows a decrease from $2.15 \AA$ in $[\mathrm{Fe}(\mathrm{bbpen})]^{+}$to $2.115 \AA$ in $[\mathrm{Fe}(\text { bbimen })]^{+}$, as a consequence of the greater basicity of the imidazole groups. A comparison of the $\mathrm{Fe}^{\mathrm{III}}$ $\mathrm{O}_{\text {Tyr }}$ and $\mathrm{Fe}^{\text {III }}-\mathrm{N}_{\text {His }}$ bond distances reported ${ }^{11}$ for human lactoferrin (Fe-O435: 1.92 $⿱$ and Fe-N597: $2.13 \AA$ ) and those presented here for 1 (Fe-O1: 1.877 (5) $\AA$ and Fe-N31: 2.269 (5) $\AA$ ) shows a good agreement. This indicates that using phenol and 1-methylimidazole groups as pendant arms in the design of ligands for model complexes, good structural approximations are obtained to mimic tyrosine and histidine amino acids.

\section{Physical-chemical properties}

IR spectroscopy and ESI-MS. The IR spectra of $\mathbf{1}, \mathbf{A}$ and $\mathbf{B}$ are quite similar and characterized by typical bands of the ligand skeletal, in addition to a band at $1094 \mathrm{~cm}^{-1}$ attributed to the $\mathrm{Cl}-\mathrm{O}$ stretching of the perchlorate anion (Figure S1)..$^{40}$ A comparison with the IR spectrum of the free $\mathrm{H}_{2}$ bbimen reveals a decrease in the band at 1372 $\mathrm{cm}^{-1}$, which indicates the coordination of the phenol group in its deprotonated form. The ESI-MS (positive mode) spectra of $\mathbf{1}, \mathbf{A}$ and $\mathbf{B}$ were recorded from freshly prepared solutions in acetonitrile (Figure S2). In fact, the spectra of $\mathbf{A}$ and $\mathbf{B}$ are identical, with the base peak (100\%) corresponding to $\left[\mathrm{Fe}(\text { bbimen) }]^{+}\right.$at $m / z^{+}$514.2. The other four observed peaks agree quite well with the predicted isotopic distribution for a $\mathrm{Fe}$ center (predicted: 514.18 (100\%); 515.18 (33.1\%); 512.18 (6.4\%); 516.18 (5.9\%) 
and $513.19(1.8 \%))$. The molar conductivities of $\mathbf{1}, \mathbf{A}$ and $\mathbf{B}$ in acetonitrile at $298 \mathrm{~K}$ are all around $130 \Omega^{-1} \mathrm{~cm}^{2} \mathrm{~mol}^{-1}$, which agrees with 1:1 electrolyte solutions. ${ }^{24}$ Therefore, we conclude that the first coordination sphere of the $\mathrm{Fe}^{\mathrm{III}}$ center is maintained intact when the complex is dissolved in acetonitrile.

$U V$-visible spectra. The UV-Visible spectra of $\mathbf{1}, \mathbf{A}$ and $\mathbf{B}$ were recorded in acetonitrile and show the same behavior with bands at identical wavelengths. The spectrum of $\mathbf{1}$ (Figure 3 ) is characterized by transitions at $\lambda_{\max } / \mathrm{nm}(\varepsilon / \mathrm{mol}$ $\mathrm{L}^{-1} \mathrm{~cm}^{-1}$ ): 236 (13500-shoulder); 278 (11300); 321 (7700) and 542 (4700). As the $\mathrm{H}_{2}$ bbimen spectrum (Figure 3-inset) has bands at $\lambda_{\max } / \mathrm{nm}\left(\varepsilon / \mathrm{mol} \mathrm{L}^{-1} \mathrm{~cm}^{-1}\right): 213$ (29000) and 276 (6100), the two bands observed for $\mathbf{1}$ at higher energy are attributed to $\pi \rightarrow \pi^{*}$ internal transitions of the aromatic rings. The bands at lower energy (321 and $542 \mathrm{~nm}$ ) can be ascribed to LMCT transitions from the $\mathrm{p}_{\pi}$ orbital on the phenolate oxygen to the half-filled $\mathrm{d}_{\pi^{*}}\left(\mathrm{t}_{2 \mathrm{~g}}\right)$ and $\mathrm{d}_{\sigma^{*}}\left(\mathrm{e}_{\mathrm{g}}\right)$ on $\mathrm{Fe}^{\mathrm{III}} \cdot{ }^{11,15-20,41}$ Comparing the UV-Visible data of $\mathbf{1}$ with those reported $^{16,20}$ for the analogous $[\mathrm{Fe}(\text { bbpen })]^{+}$, it is observed that there is a hypsochromic shift of the $p_{\pi} \rightarrow d_{\pi^{*}}$ LMCT band from 574 to $542 \mathrm{~nm}$ when pyridine groups in $\mathrm{H}_{2}$ bbpen are replaced by 1 -methylimidazole groups in $\mathrm{H}_{2}$ bbimen. These results are interpreted as a consequence of the greater basicity of the 1 -methylimidazole groups $\left(\mathrm{pKa}_{1} \cong 2.06\right)^{42}$ compared to the pyridine groups $\left(\mathrm{pKa}_{1}<1.3\right) .{ }^{43}$ This effect has also been observed in several other complexes with the same number of phenolate groups and a variety of other pendant arms with different Lewis basicity. ${ }^{17-19,41}$

The electronic spectrum of $\mathbf{1}$ was also recorded in the solid state (KBr pellets, diffuse reflectance) and revealed the same behavior observed in acetonitrile $\left(\lambda_{\max }\right.$ at 538 and $318 \mathrm{~nm}$ ), indicating no changes in the coordination sphere of $\mathbf{1}$ when in solution, in agreement with the ESIMS mass spectral data.

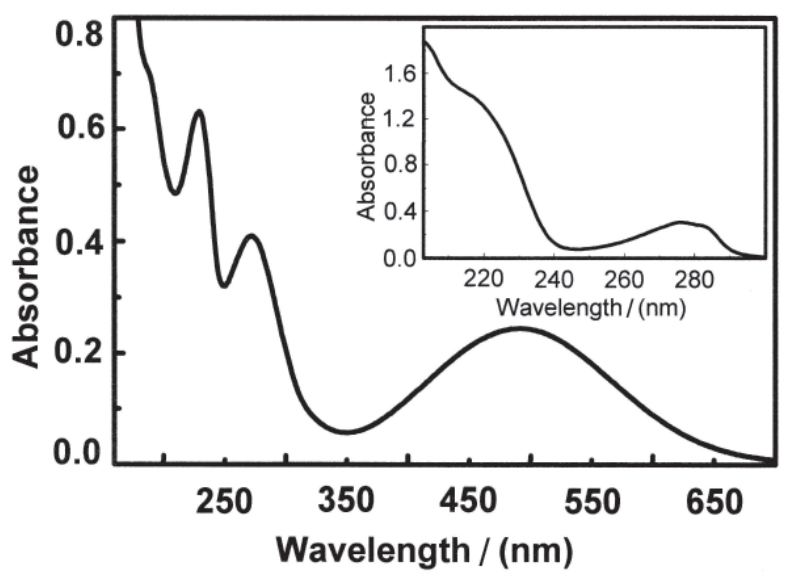

Figure 3. UV-visible spectra of $\mathbf{1}$ and $\mathrm{H}_{2}$ bbimen (inset) in $\mathrm{CH}_{3} \mathrm{CN}(5 \times$ $\left.10^{-5} \mathrm{~mol} \mathrm{~L}^{-1}\right)$.
Electrochemistry and spectroelectrochemistry. The redox behavior of $\mathbf{1}, \mathbf{A}$ and $\mathbf{B}$ was investigated by cyclic voltammetry and, as observed using all other techniques discussed above, it is quite similar. Complexes $\mathbf{A}$ and $\mathbf{B}$ have one reversible one-electron redox couple at approximately $-0.58 \mathrm{~V}$ versus $\mathrm{NHE}\left(-0.98 \mathrm{~V}\right.$ versus $\mathrm{Fc}^{+} /$ $\mathrm{Fc}$ ) ascribed to the $\mathrm{Fe}^{\mathrm{III}} \rightarrow \mathrm{Fe}^{\mathrm{II}}$ redox process (Figures 4 and S4). This value is cathodically shifted $(-0.16 \mathrm{~V}$ versus NHE) when compared to that of $[\mathrm{Fe}(\text { bbpen })]^{+}(-0.42 \mathrm{~V}$ versus $\mathrm{NHE}),{ }^{16}$ reflecting the decrease in the Lewis acidity on the $\mathrm{Fe}^{\mathrm{III}}$ center resulting from the ligand basicity increase. ${ }^{17,18}$ Regarding the electrochemical properties of transferrins, the redox potential of $-0.52 \mathrm{~V}$ versus $\mathrm{NHE}$ is in close proximity to that observed for $[\mathrm{Fe}(\text { bbimen })]^{+}$ $(-0.58 \mathrm{~V}$ versus $\mathrm{NHE})$, which indicates that it is a good model for the redox potential of transferrins.

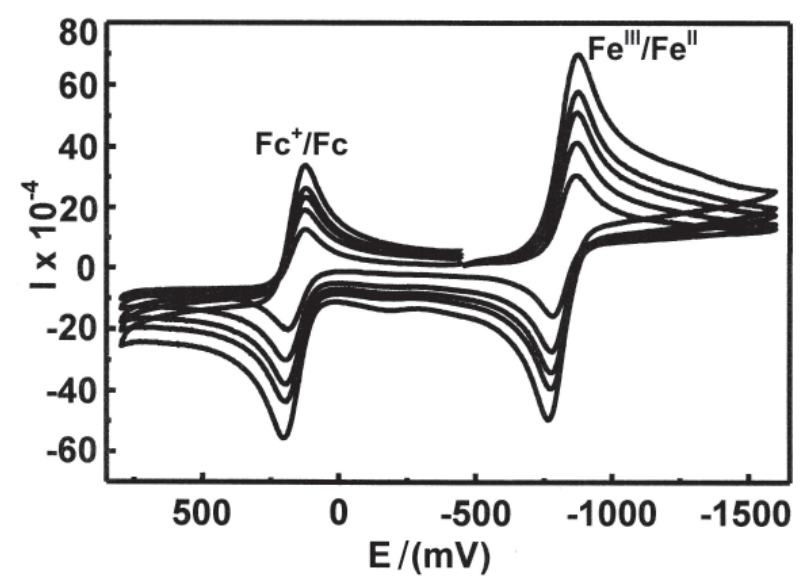

Figure 4. Cyclic voltammograms of $\mathbf{1}$ in $\mathrm{CH}_{3} \mathrm{CN}, \mathrm{TBAPF}_{6}\left(0.1 \mathrm{~mol} \mathrm{~L}^{-1}\right)$ at 50 (internal), 100, 150, 200 and 250 (external) $\mathrm{mV} \mathrm{s}^{-1}$ scan rates, $\mathrm{Fc}^{+} \rightarrow \mathrm{Fc}$ internal standard (left) and $\mathrm{Fe}^{\mathrm{III}} \rightarrow \mathrm{Fe}^{\mathrm{II}}$ (right).

In order to investigate the spectral changes during the $\mathrm{Fe}^{\mathrm{III}} \rightarrow \mathrm{Fe}^{\mathrm{II}}$ redox process, spectroelectrochemical measurements were carried out under the same experimental conditions as those employed in the $\mathrm{CV}$ studies. A decrease in the LMCT phenolate $\rightarrow \mathrm{Fe}^{\mathrm{III}}$ band at $542 \mathrm{~nm}$, with a simultaneous increase in a new band at $420 \mathrm{~nm}$ was observed (Figure 5). This band (420 nm) is tentatively attributed to an $\mathrm{Fe}^{\mathrm{II}} \rightarrow$ 1-methylimidazole MLCT transition. This kind of transition has been observed in other systems employing pyridine and pyrimidine groups as ligands, and corroborates this assignment. ${ }^{16,44}$ During the whole process an isosbestic point was clearly observed at $340 \mathrm{~nm}$. The presence of isosbestic points provides strong evidence for only two species present in solution during the redox process. Figure 5 also presents the Nernst plot, which is in agreement with the cyclic voltammetric data, and provides a redox potential of $-0.94 \mathrm{~V}$ versus $\mathrm{Fc}^{+} / \mathrm{Fc}$ for the transference of one electron in the process. 


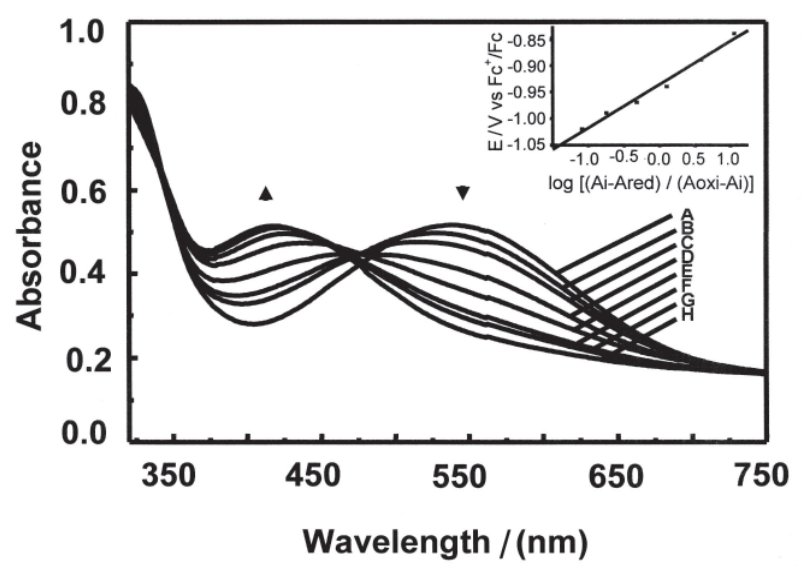

Figure 5. Spectral changes recorded for 1 during the one electron redox process $\mathrm{Fe}^{\mathrm{III}} \rightarrow \mathrm{Fe}^{\mathrm{II}}$ in $\mathrm{CH}_{3} \mathrm{CN}$. Potential range: A: no potential; B: -0.84; C: -0.89; D: -0.94; E: -0.97; F: -0.99; G: -1.02 and $\mathrm{H}:-1.06 \mathrm{~V}$ versus $\mathrm{Fc}^{+}$ $\rightarrow$ Fc. Inset: Nernst plot that provides a redox potential of $-0.94 \mathrm{~V}$ versus $\mathrm{Fc}^{+} / \mathrm{Fc}$ for the transference of one electron in the process.

\section{Proposed geometric isomers for $\boldsymbol{A}$ and $\boldsymbol{B}$}

Since EPR is very sensitive to small distortions in the coordination sphere of the metal center, it was the only spectroscopic technique able to distinguish between the two isolated geometric isomers (A and $\mathbf{B})$ of $[\mathrm{Fe}(\text { bbimen })]^{+}$. Xband EPR spectra were recorded from frozen solutions of $\mathbf{1}, \mathbf{A}$ and $\mathbf{B}$ in $\mathrm{CH}_{2} \mathrm{Cl}_{2}$ at liquid nitrogen temperature, and are shown in Figure 6.

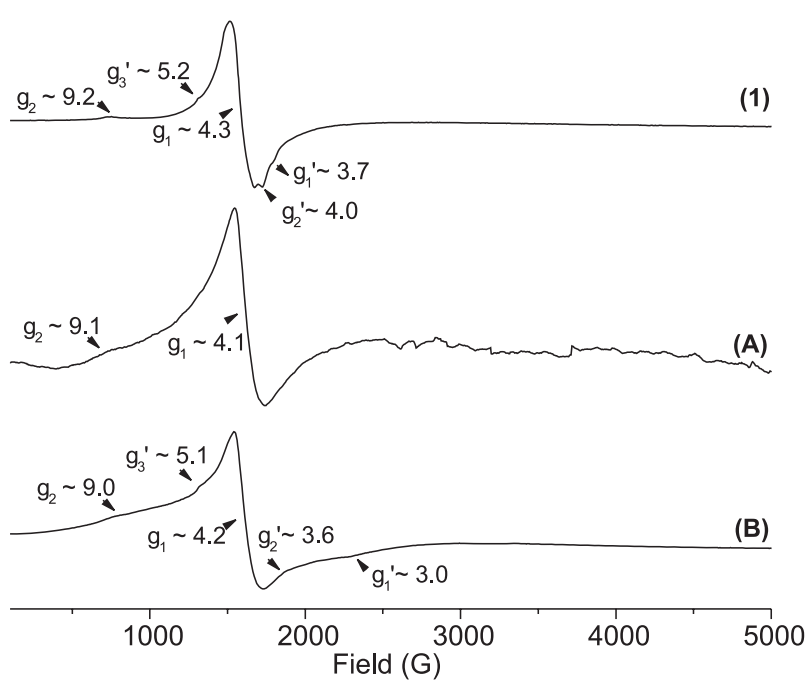

Figure 6. EPR spectra of frozen solutions of $\mathbf{1}, \mathbf{A}$ and $\mathbf{B}$ in $\mathrm{CH}_{2} \mathrm{Cl}_{2}$ at liquid nitrogen temperature.

The spectrum of $\mathbf{1}$ exhibits a sharp signal at $g_{1} \cong 4.3$, a shoulder at $g_{2} \cong 9.2$ and another $g$ set of absorption lines at $g_{1}{ }^{\prime} \cong 3.7, g_{2}{ }^{\prime} \cong 4.0$ and $g_{3}{ }^{\prime} \cong 5.2$. It is best described as a combination of the $\mathbf{A}$ and $\mathbf{B}$ spectra. The spectrum of $\mathbf{A}$ presents the sharp signal at $g_{1} \cong 4.1$ and a shoulder at $g_{2} \cong 9.1$, as expected for the middle and lower Kramer's doublet transitions of a rhombically distorted high-spin $\mathrm{Fe}^{\mathrm{III}}$ complex (E/D $\left.\cong 0.33\right)$, ground state ${ }^{6} \mathrm{~S}{ }^{45,46}$ The spectrum of $\mathbf{B}$, in addition to the peak at $g_{1} \cong 4.2$ and the shoulder at $g_{2} \cong 9.0$, also shows a set of peaks at $g_{1}{ }^{\prime} \cong 3.0, g_{2}{ }^{\prime} \cong 3.6$ and $g_{3}{ }^{\prime} \cong 5.1$, which has been assigned to weak resonances of the ground Kramer's doublets in an axial symmetry $(\mathrm{E} / \mathrm{D} \cong 0.22) .^{11,17,47,48}$

The same behavior has been observed for other octahedral $\mathrm{Fe}^{\mathrm{III}}$ complexes ${ }^{18}$ and for transferrins. ${ }^{11}$ In transferrins this may be due to the slight distortions in the $\mathrm{Fe}^{\mathrm{III}}$ coordination spheres of the $\mathrm{N}$ - and $\mathrm{C}$-lobes. Considering the similarities in the EPR spectra of transferrins and $[\mathrm{Fe}(\text { bbimen })]^{+}$, one would conclude that the complex represents a good model for the EPR properties of these metalloenzymes.

The coordination of bbimen ${ }^{2-}$ to $\mathrm{Fe}^{\mathrm{IIII}}$ could theoretically afford the three geometric isomers represented in Figure 7. As shown in our previous discussion, the geometry of one of these structures has been clearly demonstrated through the X-ray crystallographic analysis, while distinct EPR properties were found for the other isolated isomers.

Aiming to investigate the formation of these possible geometric isomers, semi-empirical studies were performed. These studies revealed that only two of the three structures (Figure 7) were confirmed as being true minimals. This was inferred by means of the vibrational frequency calculations, that showed all frequencies to be real. Calculated energies of the two optimized configurations show that (1) is favored by $c a .12 \mathrm{kcal} \mathrm{mol}^{-1}$ in relation to (2), and in spite of a relative energy difference, the results are in good agreement with the trends observed experimentally. It is also observed that only configuration (1) shows a rhombic behavior, which is in agreement with the structure shown by X-ray analysis (Figure 2), and gives a theoretical vibrational spectrum in good agreement with the experimental data (Figure S2). As the EPR studies revealed that isomer $\mathbf{A}$ has rhombic symmetry, it seems reasonable to assign it as being configuration (1). On the other hand, the geometry of isomer $\mathbf{B}$ can be assigned to configuration (2) (Figure 7). The graphical representation of the SOMO molecular orbitals for the geometric isomers $\mathbf{A}$ and $\mathbf{B}$ (Figure 8) shows that both have the main contribution of the $\mathrm{p}_{\pi}$ orbital from the phenolate groups, which corroborates the fact that similar results were observed in the UV-Visible data. As the electronic transitions (321 and $542 \mathrm{~nm}$ ) have been assigned to LMCT transitions from the $\mathrm{p}_{\pi}$ orbital on the phenolate oxygen to the halffilled $\mathrm{d}_{\pi^{*}}\left(\mathrm{t}_{2 \mathrm{~g}}\right)$ and $\mathrm{d}_{\sigma^{*}}\left(\mathrm{e}_{\mathrm{g}}\right)$ on $\mathrm{Fe}^{\mathrm{III}},{ }^{11,15-20,41}$ and both isomers $\mathbf{A}$ and $\mathbf{B}$ have the SOMO orbital with the same participation of the phenolate groups, the two complexes should have similar electronic spectra. Therefore, we have demonstrated here that the theoretical calculations describe the electronic 


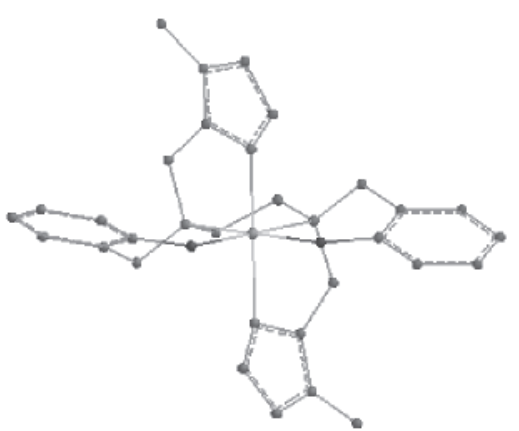

(1)

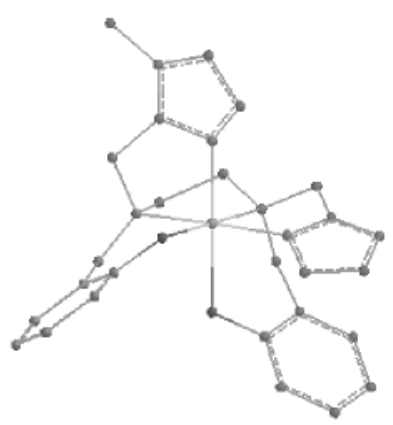

(2)

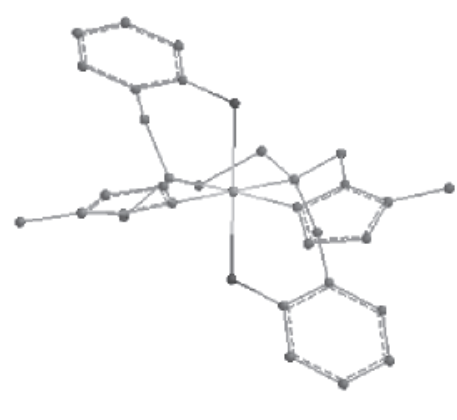

(3)

Figure 7. Representation of the three theoretically possible geometric isomers of the $[\mathrm{Fe}(\mathrm{bbimen})]^{+}$cation complex.

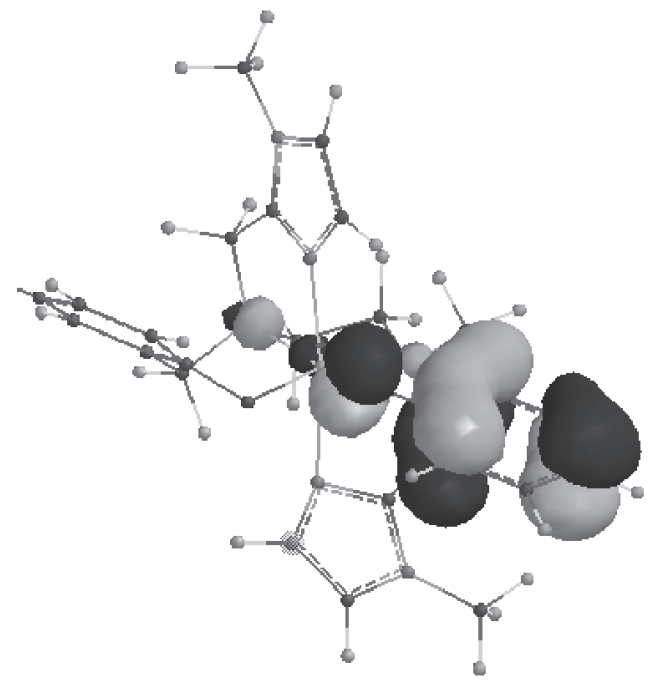

$\operatorname{SOMO}(\mathbf{A})$

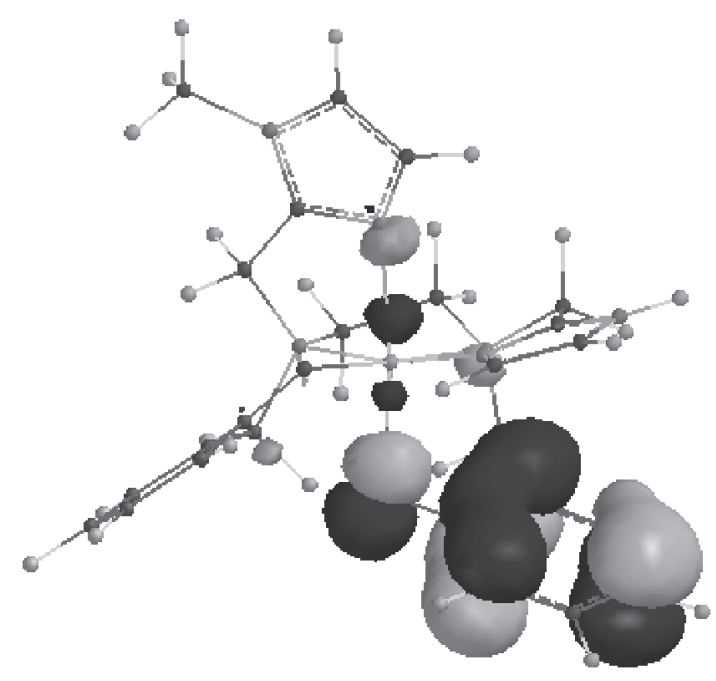

SOMO (B)

Figure 8. Graphical representation of the SOMO orbitals for the geometric isomers $\mathbf{A}$ and $\mathbf{B}$.

behavior of both isomers, and are in good agreement with the experimental data.

In spite of different calculation methods being used to obtain the data presented here for $[\mathrm{Fe}(\mathrm{bbimen})]^{+}$and those reported ${ }^{16}$ for $\left[\mathrm{Fe}(\text { bbbpen) }]^{+}\right.$, a comparison between these results showed that, in both complexes, the SOMO participation is predominantly from the phenolate groups. In addition, the LUMO of $\left[\mathrm{Fe}(\text { bbbpen) }]^{+}\right.$and $[\mathrm{Fe}(\mathrm{bbimen})]^{+}$are mainly of the pyridine and the imidazole groups, respectively.

\section{Conclusions}

In summary, we have synthesized, isolated and characterized two geometric $\mathrm{Fe}^{\mathrm{III}}$ isomers employing the ligand $\mathrm{H}_{2}$ bbimen. We have demonstrated that the substitution of the two pyridines in $\mathrm{H}_{2}$ bbpen by two 1-methylimidazole groups in $\mathrm{H}_{2}$ bbimen was successful for tuning the redox properties of $[\mathrm{Fe}(\text { bbimen })]^{+}$, making it a good model for the redox properties of transferrins. In addition, we established that EPR was the only spectroscopic technique able to differentiate the isolated isomers $\mathbf{A}$ and $\mathbf{B}$, and, when combined with semi-empirical calculations, was essential to describe their structures. It was also possible to demonstrate that the main contributions for the SOMO and the LUMO are from the phenolate and the imidazole groups, respectively, as previously observed for the analogous $[\mathrm{Fe}(\mathrm{bbpen})]^{+}$.

\section{Supplementary Information}

Crystallographic data (atomic coordinates, equivalent isotropic displacement parameters, calculated hydrogen 
atom parameters, anisotropic thermal parameters and bond lengths and angles) have been deposited at the Cambridge Crystallographic Data Center (deposition number CCDC 609269). Copies of this information may be obtained free of charge from: CCDC, 12 Union Road, Cambridge, CB2 1EZ, UK (Fax: +44-1223-336-033; e-mail: deposit@ccdc.cam.ac.uk or http://www.ccdc.cam.ac.uk). Additional Figures are also available at http://jbcs.sbq.or.br, as PDF files.

\section{Acknowledgments}

The authors are grateful for grants provided by PRONEX, CAPES, PADCT, FINEP, CNPq and Fundação José Pelúcio Ferreira to support this research. The authors also would like to acknowledge Prof. Vincent L. Pecoraro (University of Michigan, USA) for the mass spectra and the elemental analysis.

To Luiz Sérgio Gonçalves da Cunha (in memoriam). To Arlindo Scarpellini (in memoriam).

\section{References}

1. Vogel, H. J.; Aramini, J. M.; Saponja, J. A.; Coord. Chem. Rev. 1996, 149, 193.

2. Lippard, S. J.; Angew. Chem. Int. Ed. Engl. 1988, 27, 334.

3. Larson, S. M.; Rasey, J. S.; Nelson, N. J.; Grunbaum, Z.; Allen, D. R.; Harp, G. D.; Williams, D. L.; Radiopharmaceuticals: II. Procedures of the Second International Symposium on Radiopharmaceuticals; Society of Nuclear Medicine: New York, 1979, p. 297.

4. Whitney, J. F.; Clark, J. M.; Griffin, T. W.; Gautam, S.; Leslie, K. O.; Cancer 1995, 76, 20.

5. Zak, O.; Aisen, P.; Biochemistry 2003, 42, 12330.

6. Dhungana, S.; Taboy, C. H.; Zak, O.; Larvie, M.; Crumbliss, A. L.; Aisen, P.; Biochemistry 2004, 43, 205.

7. Haridas, M.; Anderson, B. F.; Baker, E. N.; Acta Cryst. 1995, D51, 629.

8. Lindley, P. F.; Bailey, S.; Evans, R. W.; Garrat, R. C.; Gorinsky, B.; Hasnain, S.; Horsburgh, C.; Jhoti, H.; Mydin, A.; Sarra, R.; Watson, J. L.; Biochemistry 1988, 27, 5804.

9. Yang, H. -W.; MacGillivra y, R. T. A.; Chen, J.; Luo, Y.; Wang, Y.; Brayer, G.D.; Mason, A. B.; Woodworth, R. C.; Murphy, M. E.; Protein Sci. 2000, 9, 49.

10. Rawas, A.; Muirhead, H.; Williamns, J.; Acta Cryst. 1996, D52, 631.

11. Ainscouch, E. W.; Brodie, A. M.; Plowman, J. E.; Brown, K. L.; Addison, A. W.; Gainsford, A. R.; Inorg. Chem. 1989, 19, 3655 and references therein.

12. Ainscouch, E. W.; Brodie, A. M.; Plowman, J. E.; Bloor, S. J.; Loehr, J. S.; Loehr, T. M.; Biochemistry 1980, 19, 4072.
13. Reyes, Z. E.; Kretchmar, S. A.; Raymond, K. N.; Biochem. Biophys. Acta 1988, 956, 85.

14. Kraiter, D. C.; Zak, O.; Aisen, P.; Crumbliss, A. L.; Inorg. Chem. 1998, 37, 964.

15. Davis, J. C.; Kung, W. J.; Averill, B. A.; Inorg. Chem. 1986, 25, 394.

16. Lanznaster, M.; Neves, A.; Bortoluzzi, A. J.; Assumpção, A. M. C.; Vencato, I.; Machado, S. P.; Drechsel, S. M.; Inorg. Chem. 2006, 45, 1005.

17. Ramesh, K.; Mukherjee, R.; J. Chem. Soc. Dalton Trans. 1992, 83.

18. Viswanathan, R.; Palaniandavar, M.; Balasurbramanian, T.; Muthiah, P. T.; J. Chem. Soc. Dalton Trans. 1996, 2519.

19. Wang, S.; Wang, L.; Wang, X. Luo, Q.; Inorg. Chim. Acta, 1997, $254,71$.

20. Setyawati, I. A.; Retting, S. J.; Orvig, C.; Can. J. Chem. 1999, 77, 2033.

21. Neves, A.; Tamanini, M.; Correia, V.; Vencato, I.; J. Braz.Chem. Soc. 1997, 8, 519.

22. Gagné, R. R.; Koval, C. A.; Lisensky, G. C.; Inorg. Chem. 1980, 19, 2854.

23. Neves, A.; Erthal, S. M. D.; Vencato, I.; Ceccato, A. S.; Mascarenhas, Y. P.; Nascimento, O. R.; Höerner, M.; Batista, A. A.; Inorg. Chem. 1992, 31, 4749.

24. Geary, W. J.; Coord. Chem. Rev. 1971, 7, 81.

25. Enraf-Nonius; CAD-4 EXPRESS. Version 5.1/1.2. EnrafNonius. Delft, The Netherlands, 1994.

26. Spek, A. L.; HELENA; CAD-4 Data Reduction Program, University of Utrecht, The Netherlands, 1996.

27. Spek, A. L.; PLATON; Molecular Geometry and Plotting Program. University of Utrecht, The Netherlands, 1997; North, A. C. T.; Phillips, D. C.; Mathews, F. S.; Acta. Crystallogr. Sect. A 1968, 24, 351.

28. Altomare, A.; Burla, M. C.; Camalli, M.; Cascarano, G.; Giacovazzo, C.; Guagliard, A.; Moliterni, A. G. G.; Spagna, R.; J Appl. Cryst. 1999, 32, 115.

29. Sheldrick, G. M.; SHELXL97, Program for the Refinement of Crystal Structures. University of Göttingen, Germany, 1997.

30. Dickic, A. J.; Kakkar, A. K.; Whitchcad, M. A.; J. Molec. Struct. (THEOCHEM) 2005, 723, 111.

31. Prasad, R.; Kumar, A.; Trans. Met. Chem. 2004, 29, 714.

32. Peixoto, A. F.; Pereira, M. M.; Sousa, A. F.; Pais, A. A. C.; Neves, M. G. P. M. S.; Silva, A. M. S.; Cavaleiro, J. A. S.; J. Molec. Catal. A: Chem. 2005, 235, 185.

33. Spartan'04 Wavefunction Inc., Irvine, CA.

34. Neves, A.; Ceccato, A. S.; Erthal, S. M. D.; Vencato, I.; Nuber, B.; Weiss, J.; Inorg. Chim. Acta 1991, 187, 119.

35. Farrugia, L. J.; J. Appl. Crystallogr. 1997, 30, 565.

36. Larsen, S. K.; Jenkins, B. G.; Memon, N. G.; Laufer, R. B.; Inorg. Chem. 1990, 29, 1147.

37. Carrano, C. J.; Spartalian, K.; Appa Rao, G. V. N.; Pecoraro, V. L.; Sundaralingam, M.; J. Am. Chem. Soc. 1985, 107, 1651. 
38. Brewer, C. T.; Brewer, G.; Jameson, G. B.; Kamaras, P.; May, L.; Rapta, M.; J. Chem. Soc., Dalton Trans.1995, 37.

39. Maeda, Y.; Oshio, H.; Tanigawa, Y.; Oniki, T.; Takashima, Y.; Bull. Chem. Soc. Jpn. 1991, 64, 1522.

40. Nakamoto, K.; Infrared Spectra of Inorganic and Coordination Compounds, John Wiley \& Sons: New York, 1970.

41. Pyrz, J. W.; Roe, A. L.; Stern, L. J.; Que Jr, L.; J. Am. Chem. Soc. 1985, 107, 614.

42. Schwingel, E. W.; Arend, K.; Zarling, J.; Neves, A.; Szpoganicz, B.; J. Braz. Chem. Soc. 1996, 7, 31.

43. Schwingel, E. W.; Ph.D Thesis, Universidade Federal de Santa Catarina, Florianópolis, Brazil, 1996.

44. Sangeetha, N. R.; Pal, C. K.; Ghosh, P.; Pal, S.; J. Chem. Soc., Dalton Trans. 1996, 3293.
45. Hendrickson, D. N.; Timken, M. D.; Sinn, E.; Inorg. Chem. 1985, 24, 3947.

46. Pal, S.; Sangeetha, N. R.; Pal, C. K.; Ghosh, P.; J. Chem. Soc., Dalton Trans. 1996, 3293.

47. Loeb, K. E.; Zaleski, J. M.; Westre, T. E.; Guajardo, R. J.; Mascharak, P. K.; Hedman, B.; Hodgson, K. O.; Solomon, E. I.; J. Am. Chem. Soc. 1995, 117, 4545.

48. Lombardi, K. C.; Guimarães, J. L.; Mangrich, A. S.; Mattoso, N.; Abbate, M.; Schreiner, W. H.; Wypych, F.; J. Braz. Chem. Soc. 2002, 13, 270.

Received: June 11, 2006 Published on the web: December 1, 2006 


\title{
EPR and Semi-Empirical Studies as Tools to Assign the Geometric Structures of Fe $^{\text {III }}$ Isomer Models for Transferrins
}

\author{
Marciela Scarpellini, ${ }^{*, a, b}$ Annelise Casellato, ${ }^{a}$ Adailton J. Bortoluzzi, ${ }^{a}$ Ivo Vencato, ${ }^{a, c}$ \\ Antonio S. Mangrich, ${ }^{d}$ Ademir Neves ${ }^{a}$ and Sérgio P. Machado ${ }^{*, b}$ \\ ${ }^{a}$ Departamento de Química, Universidade Federal de Santa Catarina, Trindade, \\ 88040-900 Florianópolis - SC, Brazil \\ ${ }^{b}$ Instituto de Química, Universidade Federal do Rio de Janeiro \\ 21945-970, Rio de Janeiro - RJ, Brazil \\ ${ }^{c}$ Instituto de Física, Universidade Federal de Goiás, \\ 74001-970 Goiânia - GO, Brazil \\ ${ }^{d}$ Departamento de Química, Universidade Federal do Paraná, \\ 81531-970 Curitiba - PR, Brazil
}

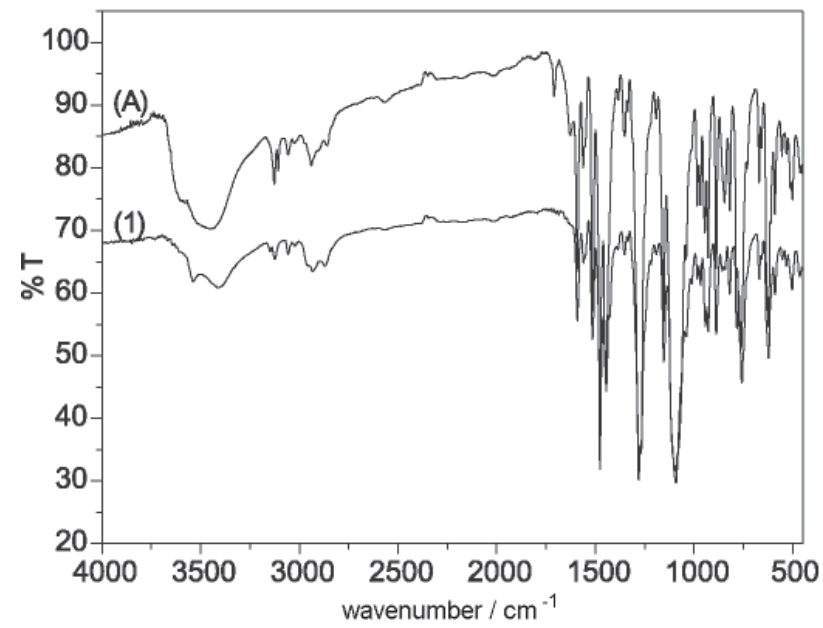

Figure S1. IR spectra of $\mathbf{1}$ and $\mathbf{A}$ recorded as $\mathrm{KBr}$ pellets.

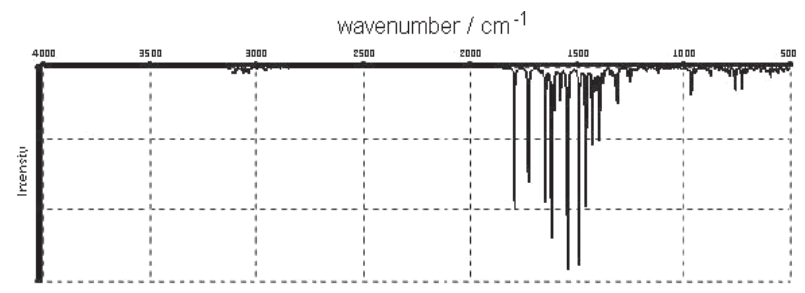

Figure S2. Theoretical IR spectrum of A.

*e-mail: sergiopm@iq.ufrj.br

Dedicated to Prof. Vincent Louis Pecoraro on the occasion of his $50^{\text {th }}$ birthday.

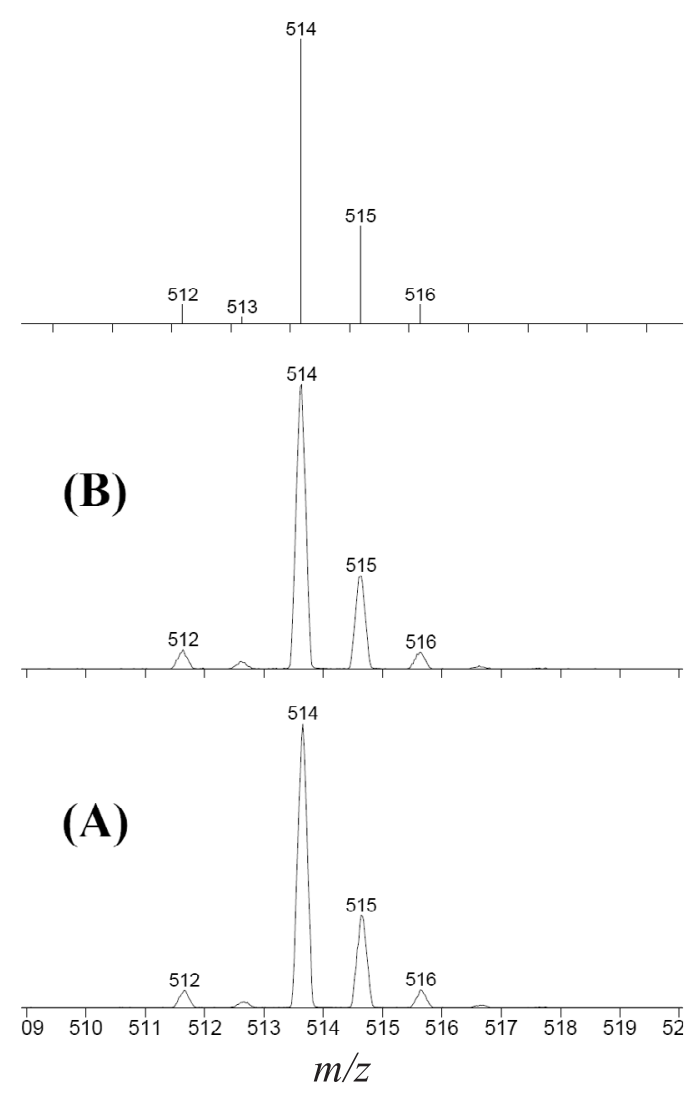

Figure S3. ESI-MS (positive mode) of $\mathbf{A}$ (bottom) and $\mathbf{B}$ (middle) recorded in acetonitrile solution, and predicted isotopic distribution (top). 


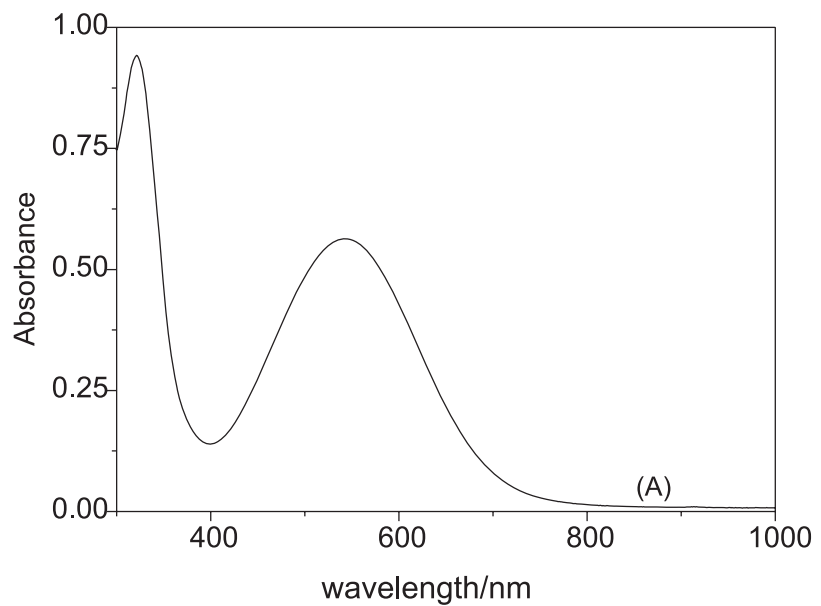

Figure S4. UV-visible spectrum of $\mathbf{A}$ in acetonitrile solution.

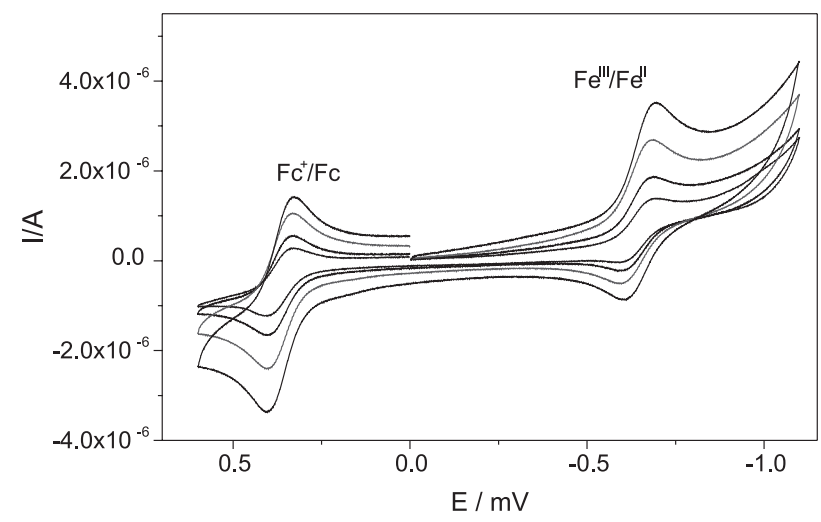

Figure S5. Cyclic voltammograms of $\mathbf{A}$ in $\mathrm{CH}_{3} \mathrm{CN}$, TBAPF $\left(0.1 \mathrm{~mol} \mathrm{~L}^{-1}\right)$ at 50 (internal), 100, 150, 200 and $250 \mathrm{mV} \mathrm{s}^{-1}$ scan rates, $\mathrm{Fc}^{+} / \mathrm{Fc}$ internal standard (left) and $\mathrm{Fe}^{\mathrm{II} /} / \mathrm{Fe}^{\mathrm{II}}$ (right). 